\title{
Reconfiguration of Arab and Middle Eastern Regions beyond Political and Economic Threats
}

\author{
Abdulrahman Al-Fawwaz ${ }^{1}$ \\ ${ }^{1}$ Humanities Department, Al-Balqa Applied University, Amman, Jordan \\ Correspondence: Abdulrahman Al-Fawwaz, Humanities Department, Al-Balqa Applied University, P.O.Box: \\ 15008, Amman 11134, Jordan. Tel: 962-7-7740-4832; 962-6479-0333. E-mail: dr_fawwaz77@bau.edu.jo; \\ fawwaz77@yahoo.com
}

Received: April 5, 2018

Accepted: May 18, $2018 \quad$ Online Published: November 30, 2018

doi:10.5539/jpl.v11n4p164

URL: https://doi.org/10.5539/jpl.v11n4p164

\begin{abstract}
Arab world and Middle Eastern region have suffered from wars and conflicts, which have resulted in creating a negative impact on the economy. In the past years, few studies have focused on discussing the impact of democratization in the Middle East and Arab region. The citizens of the Middle East region have suffered from authoritative style of governance. The democratic system is ideal for the Middle East region. It ensures that the basic fundamental rights of the citizens are protected. There are various factors, which provide hindrance in the adaptation of democratic system in both regions. This study explores major problems faced in the implantation of democratization system in the Middle East. Furthermore, the merits and demerits associated with the democratization system have also been highlighted. It has been evaluated that democratization system is beneficial for the Middle Eastern region. The implementation of democratization would be helpful in delivering benefits to the citizens. In a democratic system, the opinion of the public is considered in formulating policies. However, authoritative style of leadership and governess could cause hindrance in delivering benefits to the citizens. Thus, it can be concluded that democratization system is well-suited for Middle East region specifically. Moreover, present political setup or regime has failed to provide facilities to the public. So, public awareness should be created towards a limited democratization system as it has the capability of delivering benefits across all the sectors.
\end{abstract}

Keywords: Political and economic threats, democratization system, authoritarian, Middle East, democratic system, Arab region

\section{Introduction}

The Arab Spring witnessed major revolts against autocratic rule. Leaders of many countries were forced to step down. Furthermore, Tunisia became a parliamentary republic. The major catalysts for the revolts in Northern African and Persian Gulf countries included the concentration of wealth in the hands of autocrats that had been in power for decades, insufficient transparency of wealth redistribution, massive corruption, repression, human rights violations and especially the refusal of youth to accept the status quo (Salam, 2015). After the 2011 Arab Spring, a pressing concern has been developed to understand and examine the reasons for authoritarian regimes to remain in power despite major misgivings. Personalist dictatorships make up an increasingly large proportion of the world's dictatorships. Moreover, they tend to be particularly resistant to democratization. Understanding the conditions that increase the likelihood of democratic transitions in personalist contexts, therefore, is critical for the study and practice of democratization in the modern contemporary era (Frantz \& Kendall-Taylor, 2017). Non-democratic regional powers are increasingly blamed for authoritarian backlashes, or for the persistence of entrenched autocratic regimes in the Middle East Region. This study has made an attempt to introduce the concept of limited democratization system in authoritarian regimes to foster benefits of Democracy, moderation in religious and political thought and progress of citizens of the Arab Nations. At the same time, this new system does not completely alienate and annihilate the authoritarian system. This study has explored the positive mix of authoritarian and democratic system, by incorporating positive aspects of both the systems.

The democratic deficit and authoritarian persistence in Middle Eastern countries has neither been studied extensively nor have realistic solutions. Amongst several problems faced in Middle East region, some persistent and pervasive issues have concentrated in the hands of corrupt autocrats for decades. Moreover, certain other 
issues commonly include insufficient transparency of wealth redistribution, massive corruption, and the refusal of youth to accept the status quo (Hinnebusch, 2006). Attempts at democratization have also shown to fail consistently. A new governance system of limited democratization has been extensively researched with details of its implementation proposed to eliminate these major problems of authoritarian autocratic regimes. The new system of governance has explored the middle road between a republic form of governance and an absolute monarchy. Additionally, the problems associated with the political philosophy of too much liberalism and altruism and on the other extreme, too much control, authority, narrow-mindedness and repression have been examined and a middle ground has been proposed.

The impact of globalization and United States hegemon suggested that the international variable is compatible with liberalization of authoritarian regimes, but not with democratization (Hinnebusch, 2006). This analysis has explored the debate over the persistence of authoritarianism and the prospects for democratization in the Middle East by reviewing and critiquing various approaches, which seek to explain the conditions that obstruct or facilitate democratization and provide insight into authoritarian survival. The new concept of limited democratization expects to transform autocracy to healthy limited democratization and eventually to a healthy well-functioning Nation and Region. In this new proposed system, there is a transfer of wealth from the few to the many. Additionally, transfer of power also shifts from the dictator or the monarch to the citizens of nation. Since complete annihilation of authoritarianism is non-realistic, some powers are retained by the monarch or the dictator, but do not have a negative effect on the citizens or the political system. Moreover, the youth population feels more secure and satisfied as he/she is permitted equal participation in most spheres of life, especially being included and gaining a voice in the larger political debate of how well his/she country is functioning.

Non-democratic regional autocratic powers have been increased for the persistence of entrenched autocratic regimes in their neighborhood (Bader, Gravingholt \& Kastner, 2010). The worst case is the Arab Spring Debacle. Numerous factors led to the protests; including issues; such as, dictatorship or absolute monarchy, human rights violations, political corruption, economic decline, unemployment, extreme poverty, and a number of demographic and structural factors; such as, a large percentage of educated, but dissatisfied youth within the entire region. In this study, a new form of governance has been explored that embraced authoritarian and democratic system; thus, attempting to attain limited democratization. Major positive effects have been discovered, when the youth population are kept engaged in political processes. It has shown to decrease unemployment, reduce violence, and encourage education amongst youth. Furthermore, this new proposed system encourages pluralism, diversity, tolerance thus creating stability and progress in a country. This study of a new system of governance emphasizes on improving literacy rates and ensuring the health and well-being of the citizens. Furthermore, the problem of wealth redistribution is resolved when illiteracy decreases thus resulting in the growth of educated middle class across the region. Most importantly, limited democratization system highlights citizens' rights as being sacred and supreme in this type of governance. Oppression, repression, abuse in any way or form is punishable, and rule of law is religiously followed. Unfortunately, neither the autocratic systems nor the liberal political systems have undergone substantial positive transformation. Moreover, few studies have been examined and explored on this subject. Subsequently, a lot more attention has to be paid to this grave issue of disadvantages of authoritarian regimes and the need for their urgent transformation. Therefore, the study aims to introduce the concept of limited democratization system in authoritarian regimes to foster benefits of democracy, moderation in religious and political thought and progress of citizens of the Arab Nations.

\section{State Institutions}

State institutions play a key role in authoritarian regimes like Saudi Arabia. In Muslim countries; like Egypt and Iran, democratic elements have been adapted in political leadership. In these countries; there is a consolidation of institutions, and there are a variety of institutions working in coordination with each other. There is the executive and the legislature working in synchrony along with the electoral system that function in unison with each other. The leaders' constituencies in an authoritarian regime comprise of individuals and groups that control citizens through repression; like the security apparatus and the officer corps of the military. It is a different modus operandi in a democracy. The support of a politician's constituency comes through voting and campaign contributions. Furthermore, there is an exaggerated emphasis on the ethnic identity element, which is exploited by the leaders in authoritarian regimes. The advocacy and sponsorship of Arabism/Islamism over Nationalism has been overstretched (Telhami and Barnett, 2002).

\section{Resilience of Authoritarian}

Latest examples of the resilience of authoritarian regimes is exemplified by looking closely at Syria. Despite the Arab Spring and the wave of uprisings; Assad has proved to be a formidable force for his opponents. Other 
regional players have assisted Assad to remain in power. The additional use of narratives and words; like fitna, to degrade and lambast the opposition movements were used. This attempt of sectarianizing of uprisings has proven effective for authoritative regimes to remain in power. The prediction that the Arab Spring will subvert the prevailing regimes and bring about a democratic change was too overstated. There have been positive changes, but a lot needs to change going further. However, there have been considerable changes in the way the autocratic regimes are functioning after the Arab uprisings. Their inability to prevent mass protests and great disruptions has only made them learn from their blunders, and their rigid ways of running their countries (Lynch, 2014).

Many countries have channeled their resources with the objective of reinventing themselves and have also made major policy changes. Additionally, the public support for democracy is increasing in the Arab world. However, many still believed that Islam should play a role in political life too. Consequently, democracy with Islam was more favored than secular democracy. Best examples of this coexistence of Islam and democracy are the countries of Tunisia and Egypt. In Tunisia, Al-Nahda party won; and in Egypt the Muslim brotherhood affiliated party won. However, both parties have stated that they do not seek to impose Islamic prescriptions on the status of their women. Furthermore, both the parties shared their power with non-Islamist parties. The 'mildly' Islamist concept proved to be a great strategy to lure voters and also revealed the change in the mind-sets of citizens of these countries (Lynch, 2014).

\section{Political Transformation and Regime Configuration}

Authoritarian resilience persisted for decades around Middle East and Saudi Arabia. However, Arab Spring changed the dynamics of the region and three countries underwent major political transformation and regime configuration. They were Egypt, Morocco and Tunisia. This was the major and successful attempt made by the politicians, both in Egypt and Tunisia to isolate and alienate the radical elements, when framing the constitution of their countries. It was very to frame unthreatening and modern 'pacted constitution'. Furthermore, international financial institutions like the international monetary fund and the world bank also played a critical role in adopting a moderate Constitution, by placing conditions on these three north African countries.

Morocco is an unusual case as the country is consistently in a process of change and transformation, in spite of regime not losing its supreme authority. The Arab spring lead to two major changes. Firstly, it leads to changes in the dynamics of activism and contestation. It has majorly changed the attitudes toward their ruling process. The fall of regimes in Tunisia and Egypt had a great influence on the Moroccan authority's disposition and orientation. It weakened their confrontation with the workers and they finally had to yield to their workers' demands. This political adaptability proved to be very beneficial for the workers and the trade unions. The Moroccan regime dynamic blend of reform and repression helped them stay in power despite protests and political turmoil. The monarchy introduction and adoption of education reforms assisted them to cope with discontent. As part of their education reform, a new form of governance was introduced in public universities. Private universities were established in Egypt. Party pluralism that was being practiced in Morocco beneath the supremacy of the king exhibited the underlying change in the authoritarian regime. The contention between state and society in the three countries lead to major reforms and transformations (Rivetti, 2015).

\section{Dissimilarity between Statist and Non-Statist Islamism}

Following the success of Islamist parties in Egypt and Tunisia, this study suggests a dissimilarity between statist and non-statist Islamism. It happens in an attempt to comprehend the intricacies of interaction and communication between the State and the Islamists. Contrary to popular opinion, statist Islamists can play a major role in the democratization and the stabilization of a state. Going with the reality that Islamist organizations are part of the mainstream of political parties in many Muslim countries, their participation in the building of consensus cannot be overstated. Their positive interactions with all political and social actors is important in the national politics of a country. Any democratic transition cannot occur without their participation and excluding the Islamist parties can have repercussions and have damaging effects for the country. These statist-Islamist prioritize national politics; while the non-statist Islamists, like the armed jihadis and other extremists take religious matters into consideration. These non-statist Islamists stand to gain and take advantage of any conflict or failure in consensus building between the state and the Islamist parties. Furthermore, the non-statist Islamists do not have and do not adhere to national boundaries. They have transnational relations with other non-statist Islamists and are concentrated in the conflict areas of Middle East Region and the Arab world (Volpi and Stein, 2015).

\section{Methodology}

The introduction and implementation of limited democratization has been investigated. It has two dimensions; one of inclusiveness and the other is healthy competition. To achieve limited democratization, raising literacy, 
urbanization and non-agricultural employment have been proposed. These are the indicators of 'social mobilization' associated with an increased propensity for political participation, which translates as political and social inclusiveness (greater desire for political participation and efficacy to seek it). The king is the head of the State, and the rest of his entourage are elected by a democratic process. Thus, the reins of power, authority and control are shared equally. No repression, abuse or any trespassing of citizens' rights would be tolerated. Amongst the important factors that have been examined for the survival of this new limited democratization system are modernization, good literacy rates, separation of religion and state and progressive thinking.

\section{Results and Discussion}

Analyses of the impact of globalization on United States hegemon suggested that the international variable is compatible with liberalization of authoritarian regimes, but not with democratization (Hinnebusch, 2006). This analysis explores the debate over the persistence of authoritarianism and the prospects for democratization in Middle East by reviewing and critiquing various theoretical approaches; although, it often explains the conditions that obstruct or facilitate democratization. The new concept of limited democratization is expected to transform autocracy to healthy competition and employment, and eventually to a healthy well-functioning Nation and Region. The democratization system results in providing better opportunities to the citizens to lead a healthy and satisfied life. Many nations have benefitted through the implementation of democratic system. However, western model of democracy should not be followed in the Arab world. The democratic process or system should evolve considering various internal and external factors, which influence the system. The policy should be formulated for the welfare of the citizens. A democratic system helps in establishing law and order in the society. Furthermore, a democratic system ensures that there is a proper checks and balance system across the board. It ensures that no state institution or department abuses the use of power or authority. The democratization system makes the public representatives answerable to law (Kuyper, 2016).

The introduction of democratic system delivers wide range of benefits across the citizens, without any discrimination. The citizens in the Arab regions have suffered from dictatorship and authoritative practices. The rentier states in the Arab world have resulted in the financial stability of Gulf region. Social and cultural pressures do not influence the state decisions. Therefore, the state can formulate a policy, which is not influenced by the opinion of public. The democratization ensures that there is no need for the government officials to levy additional taxes on the citizens. The intervention of external powers directly influences Arab countries in making a policy change. Arab politicians are becoming self-aware of the fact that there are certain motives behind the intervention of Western powers. Almost all of the Arab countries have suffered from wars and conflicts; thus, it has forced Arab nations to implement a democratic system (Stavenhagen, 2016). The trends in the Arab world is changing with the passage of time; thus, the government is relaxing its policies and respecting the rights of the citizens. The citizens have been given more freedom during recent times in adopting different cultural practices within the norms of the society and region.

Post 9/11 scenario has influenced Arab officials in adopting a different approach towards providing financial stability in the region. The implementation of democratization has changed the way, the Arab world operates. It has resulted in providing more financial stability to the system. Furthermore, the economy of Arab world has observed a gradual increase during the last few years. Lowering the value added taxes means that the citizens can now enjoy better life facilities as there is less financial burden on the citizens (Wenzer, 2016). The focus of the state is to improve the financial condition of its citizens. A strong financial system creates a positive impact on the economy.

The democratization process is beneficial for the current political system; thus, it is expected to deliver benefits to the general public. This system also values the opinions of the citizen. Therefore, implementing a democratic system in the Middle East forces the government to make policies for the welfare of public. Providing valuable services to the citizens would be also significant in improving their standard of living. A positive impact is established in the job market as more number of job opportunities are created for the local public (Epstein \& Buhovac, 2014). Furthermore, there is less dependency on acquiring foreign skilled labor. The formulation of independent policies for the citizens helps in providing more opportunities to the local people. The policies should be free from external western pressure.

There is an increase in political debates in the Arab world regarding the merits and demerits of a limited democratization system. The political regime is also realizing that the implementation of a democratic system is good for the society. The dictatorship and autocracy usually result in suppressing the rights of the citizens (Stier, 2015). Analyzing the past scenarios and war situations faced by the Arab world, it is safe to conclude that the implementation of a democratic system would yield in delivering the benefits across all the sectors of society. 
The democracy empowers the citizens in raising their issues and problems across various platforms.

The implementation of democratization system improves the literacy rate of the country. A strong democratic system delivers benefits across all the sectors. The financial support and training is provided to the financially unstable and unemployed citizens. Furthermore, the democratic system ensures presence of high tolerance system in the society, a diversified political system where the views and opinions of individuals are protected (Abdelzadeh et al., 2015). A moderate and pessimistic approach is beneficial for the society.

\section{Conclusion}

The Middle East and Arab region have suffered losses due to the intervention of non-democratic and external powers in the past. During the last decade, Arab and Middle East regions have observed several wars, which have resulted in destabilizing the system. In the present context, there is a need for the implementation of a democratization system. The democratic process or system has various advantages, which includes improved standard of living related to the citizens. Current political regime present in the Middle East is resistant in the implementation of establishing a democratic system. This study has examined various factors, which are hindrance in the implementation of democratization system. The research focuses on suggesting the advantages of democratic system for the Arab region. In the past, the policies of Middle East region have been influenced by Western powers. Thus, there is a need for the Arab world to formulate independent policies for the benefit of citizens. It will provide more stability to the system. In recent times, the Arab countries have focused on reducing the percentage of value added taxes, which has resulted in reducing the financial burden on the citizens. In such a way, it is said that the democratic system is beneficial for the citizens. Adopting a moderate approach towards the future would have an influence in re-shaping the policies. In a democratic system, the involvement and engagement level of the younger generation is high. The limited democratization system is a relatively new concept or idea, which is helping in re-shaping the autocracy system. The power transfer from an authoritative leadership to a progressive leadership will also help in providing benefits to the general public. The deficit of democratic system has been an issue for the Middle East region. Thus, the research has proposed a new concept, which would help in reducing the problems faced by the citizens.

\section{Acknowledgement}

The author is very thankful to all the associated personnel in any reference that contributed in/for the purpose of this research.

\section{Conflict of Interest}

The research has no conflict of interest and is not funded through any source.

\section{References}

Abdel Salam, E. A. (2015).The Arab spring: Its origins, evolution and consequences... four years on. Intellectual Discourse, 23(1).

Abdelzadeh, A., Özdemir, M., \& Zalk, M. V. (2015). Dissatisfied Citizens: An Asset to or a Liability on the Democratic Functioning of Society? Scandinavian Political Studies, 38(4), 410-436. https://doi.org/10.1111/1467-9477.12051

Bader, J., Grävingholt, J., \& Kästner, A. (2010). Would autocracies promote autocracy? A political economy perspective on regime-type export in regional neighbourhoods. Contemporary Politics, 16(1), 81-100. https://doi.org/10.1080/13569771003593904

Epstein, M. J., \& Buhovac, A. R. (2014). Making sustainability work: Best practices in managing and measuring corporate social, environmental, and economic impacts. Berrett-Koehler Publishers.

Frantz, E., \& Kendall-Taylor, A. (2017). Pathways to democratization in personalist dictatorships. Democratization, 24(1), 20-40. https://doi.org/10.1080/13510347.2015.1131977

Hinnebusch, R. (2006). Authoritarian persistence, democratization theory and the Middle East: An overview and critique. Democratization, 13(3), 373-395. https://doi.org/10.1080/13510340600579243

Kuyper, J. W. (2016). Systemic representation: democracy, deliberation, and nonelectoral representatives. American Political Science Review, 110(2), 308-324. https://doi.org/10.1017/S0003055416000095

Lynch, M. (Ed.). (2014). The Arab uprisings explained: New contentious politics in the Middle East. Columbia University Press. https://doi.org/10.7312/lync15884

Rivetti, P. (2015). Continuity and change before and after the uprisings in Tunisia, Egypt and Morocco: Regime reconfiguration and policymaking in North Africa. 
Stavenhagen, R. (2016). Ethnic conflicts and the Nation-State. Springer.

Stier, S. (2015). Democracy, autocracy and the news: the impact of regime type on media freedom. Democratization, 22(7), 1273-1295. https://doi.org/10.1080/13510347.2014.964643

Telhami, S., \& Barnett, M. N. (Eds.). (2002). Identity and foreign policy in the Middle East. Cornell University Press.

Volpi, F., \& Stein, E. (2015). Islamism and the state after the Arab uprisings: Between people power and state power. Democratization, 22(2), 276-293. https://doi.org/10.1080/13510347.2015.1010811

Wenzer, K. C. (2016). Land-Value Taxation: The Equitable Source of Public Finance. Routledge. https://doi.org/10.4324/9781315501574

\section{Copyrights}

Copyright for this article is retained by the author(s), with first publication rights granted to the journal.

This is an open-access article distributed under the terms and conditions of the Creative Commons Attribution license (http://creativecommons.org/licenses/by/4.0/). 